\title{
True Grid: \\ Three Case Studies of Moral Accounting
}

\author{
Harro Maas
}

Received: 22 December 2018 / Accepted: 8 October 2019

(C) 2020 Ministry of Science and Technology, Taiwan

\begin{abstract}
This article examines and compares three grids that were designed to serve explicit moral accounting goals: the calculation and improvement of character. The examples are tables which fall under a broad definition of diagrams. The examples follow another in time, but it is not the article's intention to suggest a historical lineage between them. Rather, it is the intention to clarify the interplay between grids and the precepts or keys to their use. The first case is the so-called ledger of merit and demerit that was propagated by Yuan Huang, a scholar and bureaucrat of the late Ming-period, who recommended its use for moral improvement in four letters to his son, of which the most famous letter was on the improvement of one's own fate. The second is Benjamin Franklin's Art of Virtue, which Franklin in his autobiographical letter to his son equally described as a tool of moral improvement. The third is the so-called moral thermometer, or biometer, a tool developed by the French revolutionary and pedagogical innovator Marc-Antoine Jullien, who described this tool as a moral mirror and compass that would be especially of use in preparing and educating adolescents for their adult lives. All three represent generic methods of producing knowledge about an individual's (moral) character, knowledge on which the users of these tables could act. Their differences have to do with the perceived relation of moral conduct to other spheres of life, religious, social, and economic, or all of these combined, but also with the different precepts to their use.
\end{abstract}

\footnotetext{
Acknowledgments The idea for this paper emerged from a conversation with Anne Gerritsen about different forms of moral accounting. A rudimentary paper was first presented at the conference "Reasoning with Diagrams," organized by Hsiang-Ke Chao in 2016 in Taiwan. Other versions were presented at seminars in Paris, Berlin, Lyon, Utrecht, and Lausanne. I would like to thank the organizers and participants of all those events for their comments. Thanks also go to Cynthia Brokaw for providing additional information on the ledgers of Yuan Huang. Hsien-Chun Wang and Hsiang-Ke Chao kindly translated the ledger forms used in this essay. I received additional advice and support from Marylaure Bloch, Nicolas Zufferey, Ning (Laure) Zhang, Bernike Pasveer and the referees of this journal. The usual disclaimer applies.
}

H. Maas

Institute of Political Studies, University of Lausanne, Switzerland

email: harro.maas@unil.ch 
Keywords moral accounting • ledgers of merit and demerit • Franklin's Art of Virtue . Jullien's moral barometer $\cdot$ moral improvement

Over the past two decades, historians of accounting have shifted their attention from the role of accounting and accountants in business to the role of accounting, or calculative practices more broadly conceived, in everyday life. This shift in attention came in the wake of two important developments. The first was Anthony Hopwood's (1994) appeal, now twenty-five years ago, in the journal Accounting, Organizations, and Society, to pay attention to the wider cultural significance of accounting and accounting tools. The second was stimulated by Foucault's later writings on governmentality and "technologies of the self" which led to an investigation of the socially structuring effects of accounting. Both developments substantially broadened the research agenda in the history of accounting. An initial set of studies investigated the constructive work of accounting tools in the making of the "governable person" (Miller and O'Leary 1987) and the gendered character of accounting in the private and business (public) sphere (e.g., Walker 1998). A second set of studies re-examined the religious roots of accounting, also in a comparative perspective (Quattrone 2004, 2009; Yuan, Macve, and Ma 2017; Aho 2005; Coquery, Menant, and Weber 2006; Chiffoleau 2011). More recent studies have explored actual accounting practices by looking into the different spatial layouts of accounting tools (Yuan, Macve, and Ma 2017; Hoskin, Ma, and Macve 2013), as for example in a historical study that explored parallels between the work done by architectural and accounting grids and in comparative studies between Western and Chinese accounting systems (Chakhovich and McGoun 2016; Yuan, Macve, and Ma 2017; Hoskin, Ma, and Macve 2013). ${ }^{1}$

These last studies fit in with Karine Chemla's contribution to this special issue, in which she explores the importance of the spatial layout — what she calls the "diagrammaticity" - of ancient Chinese mathematical texts to their constructive role in mathematical argumentation. Chemla's attention to layout is also central in Busco and Quattrone's substantial work on the relations between spatiality and rhetoric, which builds on the notion of epistemic objects to examine the role of visualizations in accounting and their role in searching for perfection, arguing that the spatial structure of rhetoric invited a spatial representation which "later took the form of accounts written in manuals and accounting books." Busco and Quattrone note the link between three elements: topos, a space to be filled with an argument; topic, the knowledge content classified into space; and the spatial form of reasoning that went with it, known as "ratiocination," which is etymologically linked to ratio, thus establishing a link between geometry, rhetoric, accounting, and reasoning. They illustrate this link with an image originally taken from Ludovico Castelvetro's examination of rhetoric of 1653, which shows the sequence of reasoning steps distinguished in classical Western rhetoric as a geometric grid in which the different topoi are waiting to be filled.

The dimensions of the grid follow the classical rules of rhetoric, but other dimensions have also been proposed and used, such as a chronological ordering from left to right (as in Fig. 1), a classificatory ordering (who, what, where; genus, species), or

\footnotetext{
${ }^{1}$ In her contribution to this issue, Mary Morgan links the keys of maps to their topology. In the cases I studied here, the keys or prescripts to the use of tables are similarly related to their spatial layout.
} 


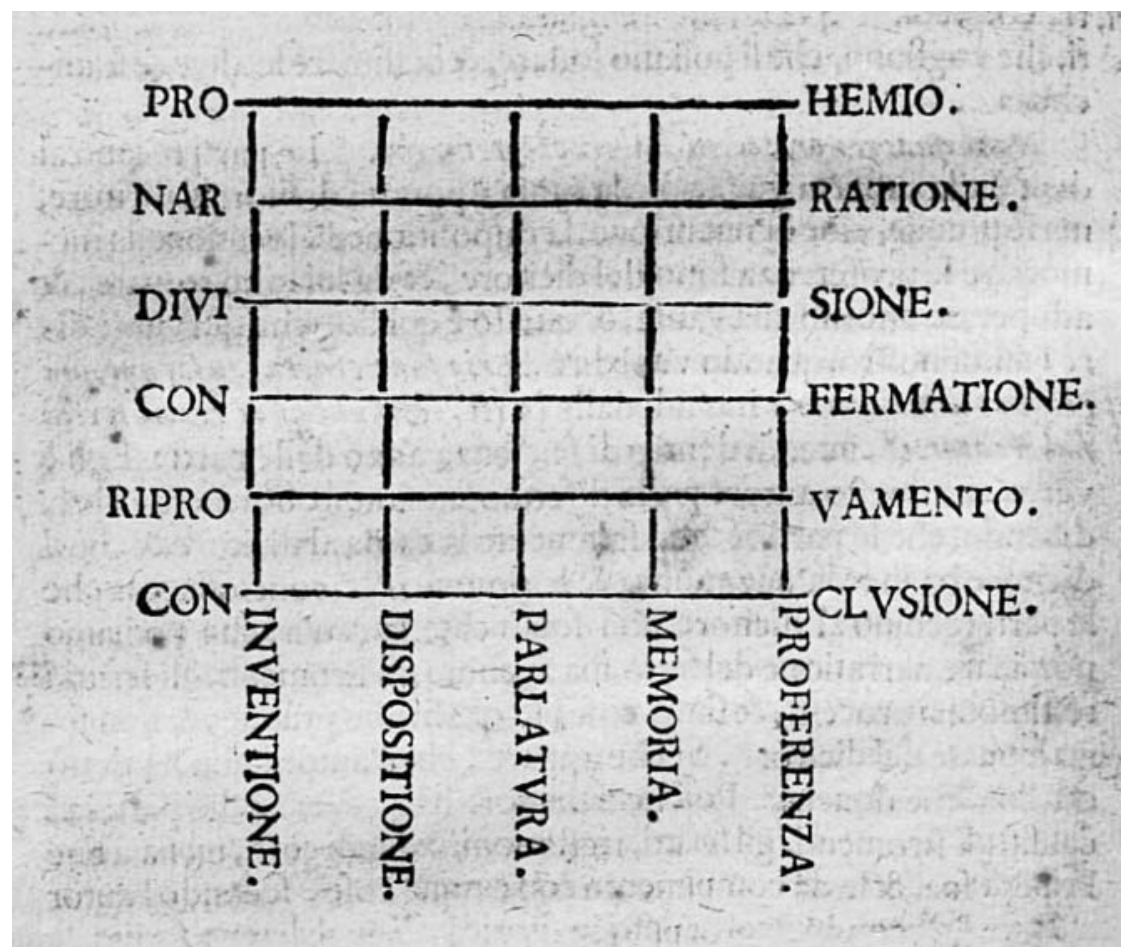

Figure 1 Page 16 of Esaminatione sopra la ritorica a Caio Herennio (Castelvetro [1653] 1983).

more complex combinations. Such dimensions enable and at the same time constrain the use that can be made of a grid. They enable an orator (to stick to rhetoric) to develop a chain of reasoning, but also restrict him or her to the formal rules that apply to a specific grid to produce a credible argument.

It is especially this last set of scholarly writing that explores the relations between spatiality and accounting that can be fruitfully connected with scholarship in Science and Technology Studies that examines technologies in terms of scripts and affordances. The latter is a neologism coined by James Gibson (1979) to emphasize that the enabling conditions of a technology are relational. That is, technologies need to be analyzed in relation to how users adapt, alter, or resist the rules according to their purposes. Along similar lines, Madeleine Akrich introduced the notion of "scripts" to analyze the use of technologies as an interplay between their intended use and how technologies can be changed, resisted, and modified by their users. Akrich (1987, 1992) emphasized that scripts cannot be analyzed solely in terms of technologies but are inherently enmeshed with the social. François-Régis Puyou and Paolo Quattrone (2018) similarly argue that accounting practices should be analyzed as a social technology.

As we can see from this short literature review, the increased attention of historians of accounting to the various roles of accounting in ordinary life has led to an investigation of the material accounting practices which shows parallels with similar shifts in attention in science and technology studies. My paper contributes to this movement by 
investigating personal accounting practices that were used to track, trace, and improve an individual's morality. In what follows, I will examine three historical instances of accounting grids that served moral improvement. I will refer to these historical instances as forms of moral accounting. The grids I discuss represent generic methods of producing knowledge about a person's character that acquired their epistemic function and practical purpose only by filling in the grid. The grids incrementally created representations of character that served the purposes of social reward and moral improvement. As has been noted in relation to script analysis, it is notoriously difficult to obtain user knowledge for historical cases (Fallan 2008). This difficulty pertains to the grids I discuss as well and will only partially be lifted in this study.

My first case concerns the so-called ledgers of merit and demerit that were promoted by Yuan Huang, a scholar and bureaucrat of the late Ming period. Yuan Huang recommended their use in four letters to his son, of which the most famous argued for the use of the ledgers to improve one's own fate. The second is Benjamin Franklin's Art of Virtue, which Franklin in his autobiographical letter to his son equally described as a tool of moral improvement that brought him health, wealth, and well-being. The third is the so-called moral thermometer, or biometer, a tool developed by the French revolutionary and pedagogical innovator Marc-Antoine Jullien, who described this tool as a moral mirror and compass that would especially be useful in preparing adolescents for their adult lives. All three served to calculate character but did so in different ways and with different consequences, which in part have to do with the perceived relation of moral conduct to other spheres of life: religious, social, and economic, or all of these combined, but also have to do with the differences between the scripts used.

\section{Case \#1: Yuan Huang and the Ledgers of Merit and Demerit}

Shortly after his death, four texts written by the Chinese provincial bureaucrat Yuan Huang were published under the title Liaofan si xun (Four Instructions from Liaofan) in 1607. Yuan Huang lived in the late Ming period, from 1533 to 1606, a period of social turmoil and substantial economic development that led to the spread of markets and a rise in status of the merchant class, traditionally considered lowest in the Chinese social hierarchy, and to the expansion of cities and the spread of luxury consumption.

The texts were written in the form of letters to his son and published under his scholarly name, Liaofan, which he had adopted after being converted to the use of the so-called ledgers of merit and demerit. The ledgers served to calculate the moral balance of a person's deeds by registering their numerical values. Yuan Huang originally probably intended his letters only for use within the family circle, just as the Yuanshi jiaxun (Yuan Family Instructions) of his ancestor Yuan Ho was likely intended but which was also published, around 1479. Both are examples of the Chinese genre of morality books, a genre that sought to educate readers about the rules of proper moral conduct. $^{2}$

\footnotetext{
${ }^{2}$ Brokaw (1991: 241-42) contains a list of morality books published in the seventeenth and eighteenth centuries. Evidence on the spread of their use to lower echelons in society is lacking until the early twentieth
} 
Since Cynthia Brokaw's $(1987,1991)$ excellent book and article on Yuan Huang's ledgers, Western scholarship has examined the social and religious context of Yuan Huang's letters, but except for Martin Lehnert's (2004) introduction and translation of Yuan Huang's letters, to my knowledge little attention has been devoted to the ledger form itself. That may be unsurprising because the original edition of Yuan Huang's letters did not contain the gridded form of the ledger. Livia Kohn (1998) has examined the historical provenance of the quantification of a person's deeds, which goes back to the Buddhist and Daoist traditions of the early medieval period. In its ledger form such quantifications became popular from the twelfth century onwards. One can easily find a large number of examples of ledgers from different periods on the internet. ${ }^{3}$ As my purpose is not purely historical, I will look at two such examples. The first stems allegedly from the late Ming period. The second stems from the nineteenth century and is taken from Martin Lehnert's edition of Yuan Huang's ledgers. By way of introducing both examples, I will provide a brief sketch of Yuan Huang's family history, and then discuss the ledger form itself.

Yuan Huang was born into a well-to-do landowning family in the province of Zhejiang. His ancestor on his father's side, Yuan Shun, a scholar and a man known for cultivating virtue, had been a high official at the Imperial Court who out of moral principles had stayed loyal to the former Emperor when Zhu Di seized the throne in 1399 and became the new Emperor in 1402. The family retreated to the periphery of the Empire, where it had to search for new means of existence. Barred from the Imperial Examinations, subsequent generations managed to regain substantial wealth by becoming physicians. Though Yuan Huang started studying medicine, he was the first who could sit again for the Imperial exams. ${ }^{4}$ Passing the exams would reopen access to positions within the Imperial bureaucracy and substantially increase the family's wealth and social prestige.

During its period of exile, remote from the Imperial court, the family had strengthened its ties with the Buddhist and Daoist religion in which ledger charts were often used for moral and religious evaluation. Kohn (1998) traced the closely related history of the celestial administration to early medieval sources. As Kohn argues, in medieval China this system of quantification made someone's fate "countable and accountable." The accumulation of merits and demerits followed an intricate system of cosmic retribution in which individuals were allotted an original real number $(S h u)$ that represented their life span and general life characteristics. Fortune-tellers and astrologists were consulted to predict what this entailed for someone's personal fate. Good and bad deeds would appear in the "celestial ledgers" and counted "toward the good fortune and eventual salvation of the person." Fate and salvation thus became "measurable items of life that could be known and described and bartered with" (Kohn 1998: 864). The balance of the ledger affected the whole family, and more in particular the family's offspring.

century, when Japanese scholars note their presence in small rural villages. The Chinese communist party adopted the ledger form in 1947 and there is still a flourishing ledger industry in Taiwan (226n140).

3 I would like to thank Anne Gerritsen for first bringing these ledger forms to my attention.

4 To qualify for the Imperial Examinations, a candidate had to give the names of his three immediate ancestors who had to be of unspoken conduct. 
Yuan Huang's important innovation was to reconcile the Buddhist and Daoist provenance of the ledgers with neo-Confucianism. In contrast with traditional belief, he did not take his personal fate as given, but as malleable and open for improvement. A substantial part of the interest in Yuan Huang's letters stems from this important change in received wisdom, a change instigated by his teacher in meditation, Yungu. His letters tell his family history, his fear of failing the Imperial examinations (which he passed only after having failed five times), and the negative prophecies about his life expectancy and male offspring. Yungu convinced him that only ordinary people considered their fate as given, but that those who set higher goals could change their personal fate by persevering and striving for excellence.

When Yuan Huang started using the ledger system, the results proved spectacular. Not only did he pass the Imperial exams, he also got a son, became a provincial administrator, and far outlived his predicted life span. In gratitude, he promised to transfer ten thousand merit points to the gods. When his wife noticed his slow pace of progress, she feared he would never be able to keep his promise. In a dream it then appeared to him how he could earn as many points at once by lowering the tax burden. All farmers in the province would benefit from this policy measure (a policy measure still popular today).

The ledger was brought to the temple and via the monks transferred to the heavenly tribunal of the gods. The ledger form thus secured a system of circulation of moral merit between the earthly and heavenly bureaucracies. The example of Huang's dream shows how both circuits, the moral and financial, could run in parallel; a tax reduction that effectively reinforced Huang's social standing as an administrator paid off his promise to the gods and reinforced his position vis-à-vis the community in his jurisdiction. A fiscal, bureaucratic measure translated in moral merit with regard to the social community under his command, and thus secured earthly and heavenly rewards. Yuan Huang's letters also suggest that with the transfer of merit points a concomitant gift went to the temple to make sure the transfer would be agreed upon by the Heavenly Tribunal of the Gods. The money transfer that probably accompanied the transfer of the balance of merits to the heavenly tribunal reinforces the parallel between heavenly and earthly rewards. Kohn (1998: 864) draws an explicit parallel between moral retribution and pecuniary investment:

Banished into numbers, fate was made predictable and came to lose some of its menace, turning from a cosmic power into a commodity that was manageable like gains and losses in material investments. The personal traits, social standing, and religious aspirations of the individual thus became investment goals in a cosmic stock market, where good and bad deeds would be exchanged in a currency of days of life and events of good fortune.

Accordingly, Cynthia Brokaw (1991) interpreted the transfer of the balance of merit/ demerit points as the transfer of a deposit to the heavenly tribunal of the gods, representing some sort of commercial or mercantile practice in which a ledger user was building "moral capital." Brokaw notes, however, that the "obvious metaphor" of moral capital was never used because profit seeking was considered a sin in (neo-) Confucian thought (207). Several neo-Confucian scholars considered Huang's texts therefore heterodox because Yuan Huang did not properly distinguish between a person's moral attitude and a person's deeds, thus reducing virtue to an arithmetic, 
utilitarian calculation similar to mercantile practices. For neo-Confucians, transfers of money and transfers of virtue were not of the same kind.

The translation of the Chinese characters 功過格 (gong guo ge) as “ledger of merit and demerit" enforces the parallel between moral and commercial accounting but is probably misleading. ${ }^{5}$ 格 (ge) is here translated as "ledger," which in English will be associated with commercial ledgers. But 格 $(\mathrm{ge})$ is not used to refer to commercial ledgers but to tables. As a noun 格 (ge) can mean "grid," "physical frame," "geometric squares," or “personal character." Martin Lehnert (2004: 22) translates 功過格 as “table of merits and demerits." The possible reference to personal character is particularly interesting, because it suggests that when a person is filling in the grid with the numerical value of his deeds, the ledger does not only register his deeds but in the process also reveals with numerical precision this person's character. The table becomes a visual, numerical representation of a person's moral worth.

\section{The Ledger Form}

From these truncated histories of Yuan Huang's life and the ledgers of merit and demerit, it should be obvious that the use of a tool is indispensable to account for one's deeds. Such a tool would serve a mnemonic function, but also as a résumé of one's moral balance when turning to the temple for a transfer to the eternal tribunal of the gods. Let us now look in more detail at examples of such ledger forms.

Figure 2 reproduces the example discussed by Lehnert, which lists the months vertically, and the days of the week horizontally. Below the days of the week, columns alternate for acts of merit and demerit. The form is read chronologically, from right to left, and from top to bottom. Users were supposed to insert the number of merit or demerit points per day into the grid and to calculate the balance. At the extreme left there is space for the balance of merit over individual months. At the bottom there is room for notes. The form itself does not provide guidance to its user about how and what acts should be valued. Brokaw includes a long list of deeds of merit and demerit but does not explain its use in practice nor gives their numerical value. In his translation of Huang's letters, Lehnert includes an extensive discussion of similar lists and how an individual receives merit or demerit points for his deeds as well as a list of moral retributions, or moral payoffs, for different annual moral balances. The list reproduced by Lehnert contains, for example, "building warehouses and stabilizing prices (of rice and wheat)," which earned one merit point, and "saving the life of a useless animal," which earned three. "Preventing the drowning of a girl which would prevent another family from having male offspring" earned one hundred merit points, while "possessing arms to kill or entertaining murderous thoughts" earned ten demerit points. "Raping a woman" earned one hundred demerit points, and so on. Clearly, the number of points attributed to different kinds of deeds entails a moral order. As with modern nudging policies, the different number of points attributed to different deeds will encourage an individual to adjust his or her behavior accordingly. Thus, a monthly

\footnotetext{
5 For recent histories of commercial accounting in China, see Yuan, Macve, and Ma 2017, and Guo et al. 2011.
} 


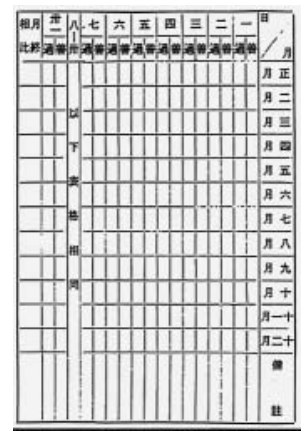

Figure 2 Fragment of a monthly ledger (Lehnert 2004).

balance could be calculated against which stood specific moral remunerations (with extensions to material wealth). Lehnert explains how a net balance of merit points of two hundred secured that one's own name would be positively remembered after one's death, and sons and cousins would live in wealth. With sixty points one would not be harmed and would not be troubled by evil people. Sixty demerit points by contrast would leave someone childless, and three hundred demerit points would leave one's offspring poor for several generations (Lehnert 2004: 118-21).

The gridded form included in Lehnert's edition is by itself not sufficient to include the details of such a list. A grid of months and days of the month does not provide the necessary detail to list individual deeds. Users will need another tool to calculate the daily totals. For this purpose, the more complex ledger form in Figure 3 seems better suited. This ledger also puts the social and intergenerational meaning of the ledger form in sharper relief(Fig. 3). Reading from right to left, the column at the right indicates the days of the week. The upper rows list several categories that are subdivided into subcategories in the second row. Alternating as in the first example are then columns headed with 功 (merit) and 過 (demerit) in which merit or demerit points should be listed.

The categories and subcategories read as follows:

1. 敦倫格 The Grid for Advancing Ethics

父母. Parents

兄弟 Brothers

夫婦 Husbands and Wives

子孫 Descendants

宗戚 Relatives

師友 Teachers and Friends

主僕 Masters and Servants

2. 修身格 The Grid for Self-Cultivation

致知 Acquisition of Knowledge

心性 Disposition

出言 Manners of Using Language

待人 Manners of Treating People

交財 Manners of Dealing Finance

遏邪 Suppression of Evil Thoughts

敬惜 Respect and Cherish of Papers 


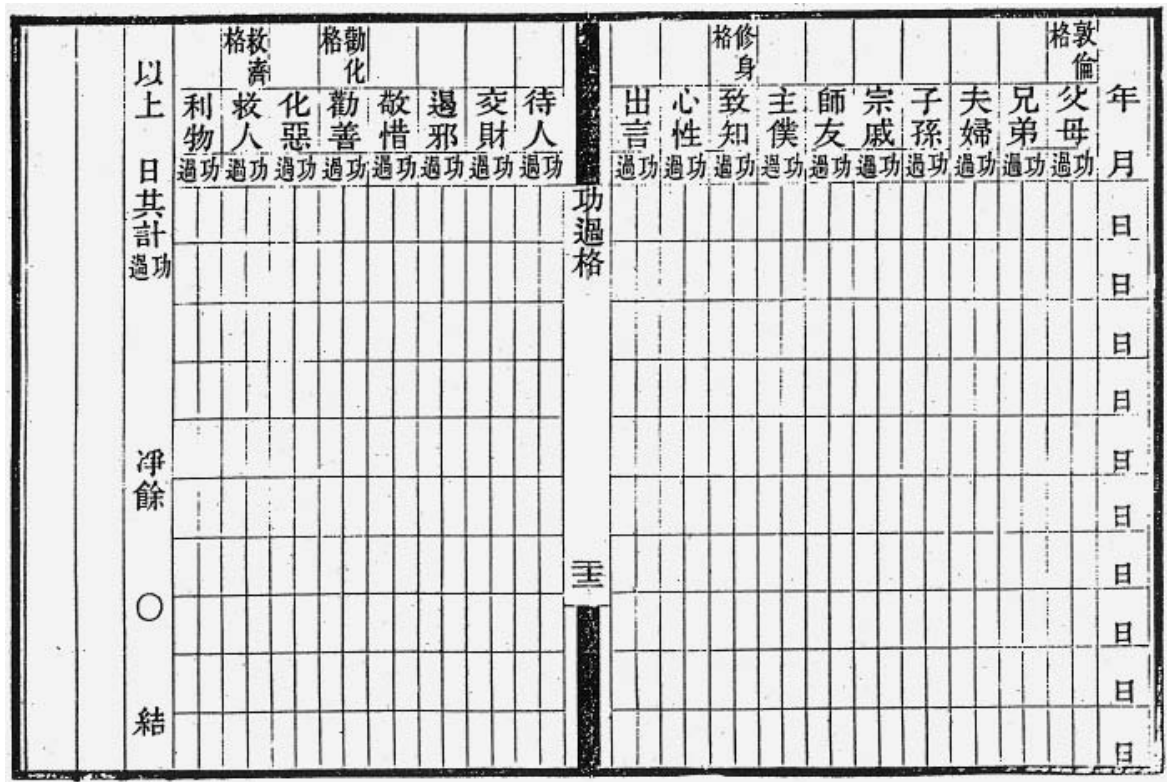

Figure 3 Ledger from a later edition of Yuan Huang's four letters to his son (Huang 1988).

3. 勸化格 The Grid for Promoting Good Behaviors

勸善 Encouraging Good Behaviors

化惡 Discouraging Bad Behaviors

4. 救濟格 The Grid for Providing Benefit 救人 Calamity Relief

In this second example the order of the different categories themselves guides the attention of its user to key relations in Confucianism and forces users to be specific about the category affected by their specific deeds. Daily totals can then be calculated, which subsequently can be totaled over a month. First comes the promotion and wellbeing of the (extended) family and its offspring, the relations within the family and the household, such as those between husband and wife or master and servants. Then comes personal care. The subcategories tell us something about whether a person is studious, diligent, and orderly in matters of physical and mental hygiene, but also in financial and social matters. The third and fourth categories tell us if this person is actively encouraging good deeds, including acts of charity.

As in the first example, this complex of actions is summarized in one number that is then transferred to one's karma. Though only the final balance of merit and demerit points is transferred, the table invites its users to review how their deeds affect the different categories of their lives. The values of the deeds inserted become an imprint of its user's character that at once represent the effects of his actions on the social world in and on which he acts. It is this double alliance, to the personal and the social, that makes it conceivable how filling in the grid will be of consequence for a person's own and for his family's health, well-being, and reputation. 
By cultivating his deeds and concentrating on specific (categories of) actions, someone could improve his moral balance and hence his personal character. This would reflect well on himself, his family, his siblings, and his children, and would establish his name, and the name of his family, as virtuous and trustworthy. Through the registration of his deeds, the ledgers showed his character and moral worth. By filling out these forms, day by day, week by week, the acts vanished behind the numbers, but what did not vanish, indeed, what became a clear and stable fact, is the kind of person the table represented, with its implications for his social environment. Did he treat his parents and brothers well? Was he well-behaved regarding his wife? Did he treat his servants well? Were his finances in order? Was he taking care of the poor? Was he encouraging others to do good? The form provided a clear, numerical answer to such questions, and summed up their grand total in one aggregate number in the circle on the left: this is who you are, this is what you are worth. Following Yuan Huang, this worth was not a static fact; the table was a tool that could make one's merit evolve, transform, and improve.

The table could not do this on its own. We have seen there was a list of merit and demerit points that should be used to fill in the grid. These lists could be different, just as there were different formats of the table itself. There were procedures to be respected, such as the handing in of the table at the temple with possibly a concomitant money transfer or the secrecy around one's own balance of merit. Without these rules and procedures, the table could not do its work. But without the table, a merit transfer could not take place either, and a person could not get a clear image of his character, nor of the improvements he made to it. Put otherwise, the entanglement of tools, rules, and procedures created an infrastructure that ensured the effectiveness of the ledger method. Yuan Huang reinterpreted the rules of the method to make it fit the novel idea that it was possible to change one's fate by filling in the grid. His personal life served as conclusive evidence.

\section{Case \#2: Benjamin Franklin's Art of Virtue}

My second example of a moral accounting grid is Benjamin Franklin's Art of Virtue. In contrast with the ledgers of merit and demerit, which tracked and measured a person's moral value in relation to his social environment, Franklin's Art of Virtue relied on a tracking device that registers moral progress in terms of self-control. Franklin described his Art of Virtue in his autobiography (Franklin 2004), which was partly written in the form of a letter to his son. It was published posthumously in 1791, first in a garbled French translation which became the source of many other translations. ${ }^{6}$ The Autobiography tells the story of a successful life that pays little attention to Franklin's role and involvement in the War of Independence, but much to his successes in business and his shifting attitudes towards religion. Franklin recounted how he started developing a self-help system for moral improvement in the same period he stopped

\footnotetext{
${ }^{6}$ Franklin's grandson, William Temple Franklin, who was in charge of his literary bequest, made substantial changes to the original text, and it was only after John Bigelow got hold of the original manuscript that Franklin's autobiography was published in its original form in 1868. Franklin had been working on his memoirs since 1771 .
} 
attending church and he ascribed his major successes in life to this system, the Art of Virtue. He highlighted two characteristics of this system that he considered particularly important. First, he had designed a system of virtues that was general enough for a person of any religion to recognize its merit and usefulness. Second, he emphasized its practical usefulness to improve character, in contrast with a generic appeal to do good.

It had struck Franklin how often habit or simple inattention had made virtue slip away. To counteract this tendency, he designed a mnemonic device to train himself more systematically in the cardinal virtues by tracking his moral record. Finding himself confounded over the exact meaning of the cardinal virtues, he decided to extend their number, while limiting their meaning to a specific rule of action. He settled on thirteen virtues (after being prodded by a Quaker friend to include humility, which he admitted was not his forte). In his autobiography, Franklin refers to these virtues as character traits. Franklin reserved one page for each virtue in a small booklet which he accompanied with a short precept, or rule of action "which fully express'd the extent I gave to its meaning." Temperance, for example, was explained with the precept "eat not to dullness, drink not to elevation." Order was explained with "let all your things have their places; let each part of your business have its time."7 On these pages, he drew a table that listed the days of the week horizontally and the thirteen virtues, including the one specifically under consideration, vertically.

These virtues were listed in an order that would prepare his state of mind, or so he argued, more easily for the next one. Because Temperance produced "coolness and clearness of head," it came first. Silence would then prepare him for Order, and so forth. He would then follow a fixed procedure to train him in these virtues. As he considered it would be impossible to concentrate on all virtues at once, he would start with the first, Temperance, leaving the others to their natural course, but marking any faults with a dot. In the example he included (Fig. 4), we see a clean slate for Temperance, but two dots for violating Silence on Sunday, indicating that he had engaged in "trifling" or useless conversation and thus had wasted his or someone else's time.

After having concentrated for a week on Temperance, he would move to the next virtue, Silence, trying to now keep two rows empty. He would then include the third, and so on. After having completed the full cycle, he would return to the first. The final goal was to end with an empty table - no dots. After having used his little book for a while, Franklin inscribed the table on "the ivory leaves of a memorandum book," drawing the table in permanent red ink, and adding the dots with a pencil that could easily be erased. After several years of regular practice, he diminished the number of

\footnotetext{
7 Franklin's complete list was as follows: temperance ("Eat not to dullness; drink not to elevation"); silence ("Speak not but what may benefit others or yourself; avoid trifling conversation"); order ("Let all your things have their places; let each part of your business have its time"); resolution ("Resolve to perform what you ought; perform without fail what you resolve"); frugality ("Make no expense but to do good to others or yourself; i.e., waste nothing"); industry ("Lose no time; be always employ'd in something useful; cut off all unnecessary actions"); sincerity ("Use no hurtful deceit; think innocently and justly, and, if you speak, speak accordingly"); justice ("Wrong none by doing injuries, or omitting the benefits that are your duty"); moderation ("Avoid extremes; forbear resenting injuries so much as you think they deserve"); cleanliness ("Tolerate no uncleanliness in body, cloaths, or habitation"); tranquility ("Be not disturbed at trifles, or at accidents common or unavoidable"); chastity ("Rarely use venery but for health or offspring, never to dullness, weakness, or the injury of your own or another's peace or reputation"); and humility ("Imitate Jesus and Socrates") (Franklin 2004: 68-69).
} 
Form of the pages.

\begin{tabular}{|l|c|c|c|c|c|c|c|}
\hline \multicolumn{7}{|c|}{ TEMPERANCE. } \\
\hline \multicolumn{7}{|c|}{ EAT NOT TO DULNESS; } \\
DRINK NoT TO ELEVATION. \\
\hline & S. & M. & T. & W. & T. & F. & S. \\
\hline T. & & & & & & & \\
\hline S. & $*$ & $*$ & & $*$ & & $*$ & \\
\hline O. & $* *$ & $*$ & $*$ & & $*$ & $*$ & $*$ \\
\hline R. & & & $*$ & & & $*$ & \\
\hline F. & & $*$ & & & $*$ & & \\
\hline I. & & & $*$ & & & & \\
\hline S. & & & & & & & \\
\hline J. & & & & & & & \\
\hline M. & & & & & & & \\
\hline C. & & & & & & & \\
\hline T. & & & & & & & \\
\hline C. & & & & & & & \\
\hline H. & & & & & & & \\
\hline
\end{tabular}

Figure 4 Sample table from Benjamin Franklin's Art of Virtue regarding temperance. Any fault regarding the other virtues is marked with a dot; thus, we see Franklin did not respect order twice on Sunday (Houston 2008).

cycles he practiced until his busy life of business and travel prevented him from attending to his Art of Virtue altogether.

Franklin's moral tables enabled him to keep track of his moral progress in terms of self-control. While the ledgers of merit and demerit were part of an infrastructure in which moral values circulated between individuals and the social and religious order, Franklin's tables were primarily centered on his individual performance and did not circulate to an outside world. But Franklin was convinced that the strengthening of his character was of consequence for his worldly performance. He ascribed his personal fortune and well-being to "this little artifice" that he "with the blessing of God" had practiced for a substantial period of his life. Franklin considered that respecting Temperance had brought him his "long-continued" good health, Industry and Frugality, his early material fortune and a reputation as a "useful citizen," Sincerity and Justice, the trust that was put into his political endeavors, and to all the other virtues his reputation as a socially agreeable person. The tables had served him to exercise restraint. They had made his moral progress visible and had served as a check on his progress.

\section{Case \#3: Marc-Antoine Jullien's Biometer}

Yuan Huang's and Benjamin Franklin's texts were written, in whole or in part, as letters to their sons. Both explained a procedure to improve one's moral character. In Yuan Huang's case, this procedure was embedded in religious traditions of which the roots went way back in history. Franklin presented his procedure as of his own invention, and 

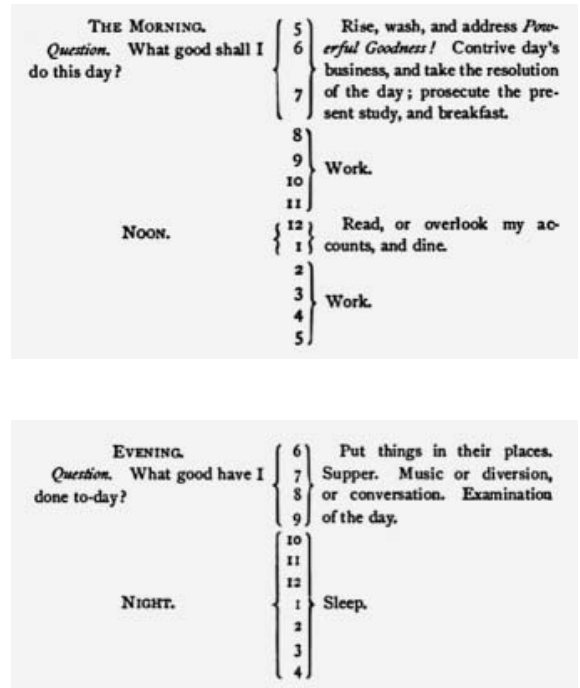

Figure 5 Benjamin Franklin's daily routine for keeping order (Houston 2008).

whatever origins it may have had in Christian traditions, it certainly was not the double entry bookkeeping procedure that Werner Sombart considered so distinguishing for the emergence of capitalism (Yamey 2005). Yuan Huang gave a new meaning to an already existing procedure; Franklin designed what comes closest to a self-help instrument for moral improvement. Yuan Huang's instrument compressed specific valuations in a global number; Franklin's registered unspecified failures per virtue to which he would have to devote more attention to strengthen these virtues as character traits. A fully successful cycle would leave the table empty and make him a man of perfect character.

My third example of a moral accounting grid is the so-called moral thermometer or biometer developed by the French revolutionary and pedagogical innovator MarcAntoine Jullien, designed in the early nineteenth century. In a series of imaginative essays, Philippe Lejeune has provided in-depth discussions of Jullien's instrument and what follows will draw on Lejeune's work (Lejeune 2011; Lejeune and Bogaert 2003). Jullien's biometer is closely related to the virtue that posed Franklin most difficulties: "order." 8 To explain this virtue, Franklin included a scheme of activities for the day (Fig. 5):

Franklin's scheme for order decomposed his precept "Let all your things have their places; let each part of your business have its time" into several distinct categories which can be summarized as follows: personal hygiene and self-care, work, sociality, storage of matters and reflections on the day. Franklin attributed hours of the day to each of these categories. His way of marking failures by dots in his moral table did not

\footnotetext{
${ }_{8}$ Franklin was not known as a very orderly man. Visitors wondered how it was possible for someone to maintain a business with papers, bills, and books spread all over the place, seemingly haphazardly. Franklin complained to himself about his disorderly nature, and his "want of method" in finding the right place for "things" and "papers," which he partly blamed on his "exceeding good memory." Hardly making progress, Franklin almost gave up on this virtue.
} 
allow him to distinguish in which category he had failed. ${ }^{9}$ Reviewing the table, one, two, or three dots for violating order would not tell Franklin to what part of the day or to what category of his activities he should direct his attention. To improve on his conduct would depend on - as he wrote - his "exceeding good memory," but not on this table as such.

Jullien's biometer enabled its user to review which category of deeds was affected by his conduct. In one of the essays in which Jullien explained the working of the table, he included lengthy abstracts from Franklin's autobiography, and it may be that Jullien directly build his biometer from Franklin's table for "order."

As in the two previous cases, it will be helpful to provide some biographical information on the maker of this third moral accounting tool. Marc-Antoine Jullien's life spanned the period from the American War of Independence to the French June Revolution of $1848 .{ }^{10}$ He actively participated in the French Revolution, lived through the Thermidor and the Napoleonic period and the Restoration. He died just before Napoleon III became president of the French Republic after the revolution of 1848 . He showed great interest in the unfolding industrial revolution, visited Robert Owen's New Lanark and wrote an introduction to a French translation of Owen's writings. This Jacobin revolutionary who according to Palmer turned liberal under the Bourbon Restoration became best known as educational reformer who was much influenced by the Swiss Johan Pestalozzi and Philip Emmanuel von Fellenberg, for whom monitoring systems were an important element of their pedagogical reform programs. He was the founding editor of the Revue encyclopédique (founded 1819), a journal devoted to the popularization of science. Jullien developed his moral thermometer, or biometer as he later came to refer to it, in this pedagogical context.

Jullien first published on his biometer in a small tract titled Essai sur l'emploi $d u$ tems ou méthode qui a pour objet de bien régler l'emploi du tems, originally published in 1808 (Jullien 1810, 1813, 1835). In the introduction he explained he had developed the biometer while still in the army and with an eye on its usefulness for his own children. Stimulated by its positive reception, also outside of France, Jullien continued publishing on his biometer, either in separate publications (such as his Horaire ou Thermomètre d'emploi du tems, published in 1813), or in increasingly lengthy versions of his original essay.

Jullien proposed the biometer as part of a complete system of books designed to organize, regulate, and control the various domains of one's life. Jullien recommended 1) the use of a journal of facts and observations, and 2) a list of specialized books comprising a financial ledger, a journal and cash book, a register of letters sent and received, and a record of books (to be) read. The third category was the biometer itself, which was designed to minutely register the time devoted to these various domains of life. Jullien compared his system with the "commercial method of bookkeeping which had so importantly contributed to the recent advancement of societies."

\footnotetext{
9 Elsewhere, I have investigated how an ardent user of Benjamin Franklin's Art of Virtue, the Genevese pastor François-Marc-Louis Naville (1784-1846), introduced different symbols to mark failures with regard to different aspects of the virtue he concentrated on. See Maas 2019.

10 He was referred to as Jullien "of Paris" to distinguish him from his father. On Marc-Antoine Jullien, see Palmer 1993; Lejeune 2011; and Di Rienzo 1999.
} 


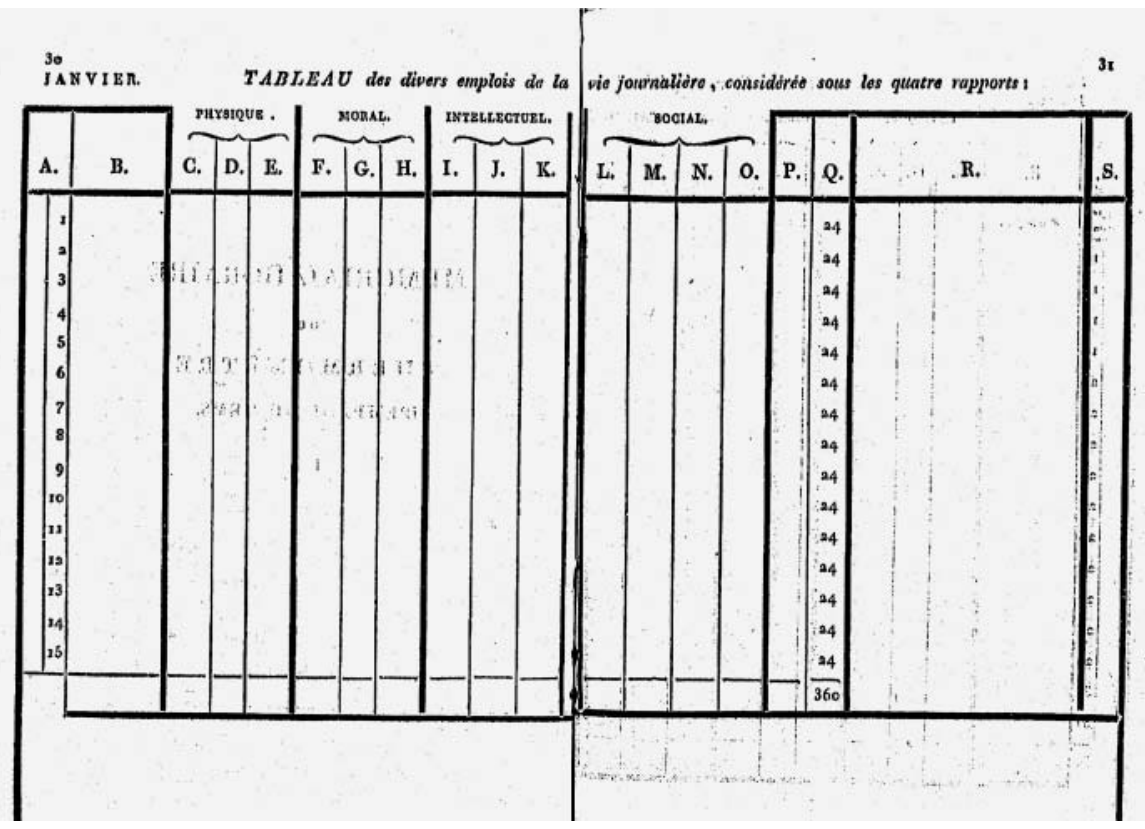

Figure 6 Marc-Antoine Jullien's moral thermometer or biometer (Jullien 1813).

Our books (of moral accounting) offer a perfect similarity with the ledgers of merchants and bankers and with the comparisons of bulletins of market places that inform you at a glance about the rise and fall in the value of government bonds or of the commodities in each. We transpose the current accounts of trade in our moral methods; and, every day, in just a few moments, we make up a detailed account of our expenditure in the last twenty-four hours. (quoted in Lejeune 2011)

The last sentence clearly referred to the biometer, that is, to a detailed account of the expenditure of time over the whole day. The biometer consisted of a table of columns headed by capital letters (Fig. 6). Jullien distinguished between someone's inner and external life. A person's inner life was subdivided into three categories: physical, moral, and intellectual, which were equally subdivided. Half a month's days were listed vertically (with the next half of the month on the next page). A "d" and a " $\mathrm{j}$ " indicated Sunday (dimanche) and Thursday (jeudi) so that one could recognize the days of the week at a glance. The first column (A) gave the dates of the month. The second column (B) provided meteorological data about temperature, rainfall, and so on, suggesting that not only mercantile books but also medical diagnostical tools may have informed the design of the biometer. ${ }^{11}$ A person's physical life consisted of three columns: sleep, food, and physical exercise. Physical exercise included country walks, horse rides, hunting, but also taking a bath. Moral life was also divided into three columns, devoted to religious, family, and economic life, respectively. Economic, intellectual (obligations, work of choice, readings), and social life (correspondence,

\footnotetext{
${ }^{11}$ In medical diagnostics, connecting meteorological to nosological observations was common practice. See Mendelsohn 2011; Hess and Mendelsohn 2010.
} 
travels, social visits, cultural events) were also subdivided. Jullien suggested that someone could further specify the time written down in these columns by letters that indicated, for example, how much time in bed was spent on reading, or with fever, and so forth. The last four columns, P, Q, R, and S, were evaluative columns, on which more below.

The categories and subdivisions of the table can be interpreted as an extended version of Franklin's scheme of the day that indicated his activities without specifying them in detail. They also reproduce some, though not all, of the categories of my second example of a ledger of merit and demerit: personal and family care, intellectual and social life. In contrast, the acts are not numerically evaluated according to their substance, but according to a ruler that homogenized their duration: clock time.

\section{Scheduling Life: François-Marc-Louis Naville's Use of the Biometer}

The emphasis on clock time as a measure of moral value was consistent with the weight clock time had gained in the Calvinist world. For Calvinists, the thrifty use of the time attributed to an individual by God was an important measure of a person's moral worth. Max Engammare (2010) even speaks of the development of time-management in Protestant Geneva as the development of "Calvinist time." Jullien was not a Protestant, but he was well acquainted with the Calvinist circles in Geneva. Figure 7 shows the hand-drawn table of one of the users of Jullien's biometer. It is taken from a series of notebooks of a Genevese pastor, François-Marc-Louis Naville (1784-1846), who was himself a pedagogical innovator interested in new ways of monitoring the progress of his pupils.

Figure 7 shows at a glance how the table mirrored the time devoted to the different categories of life. In the case of Yuan Huang's ledgers and Franklin's Art of Virtue, the points and the dots were themselves already morally loaded. Jullien's table reframed virtue in terms of time. Should more time be spent on physical hygiene or on financial affairs? Was too much time spent on work or on social interaction? Was sufficient time devoted to religious meditation (in Fig. 7, Vie Anagogique, anagogical life)? To enable such evaluations, a schedule was needed that would specify how much time should be devoted to each separate category in the table.

Such a schedule followed from the other books Jullien recommended to be kept. Naville calculated a partial schedule for his intellectual life in the first pages of his daily planner by calculating the total number of hours devoted to the study of languages and the various sciences, and recalculating that to the number of hours per day. In Figure 7, we can see this in the double underlined numbers. Below the table, still in Figure 7, Naville registered the number of hours he had fallen short on this schedule, and these hours became time to be made up in the future. It will be unsurprising that Naville included such schedules, specified to quarters of an hour, in his own tract on pedagogical reform, and that he considered these schedules to serve the overarching goal of moral perfection of a pupil's character.

\section{Time, Pleasure, and Pain as Moral Measures}

The moral significance of the use of time can be seen most clearly from column P, which indicated hours lost, for example by circumstances outside of someone's 


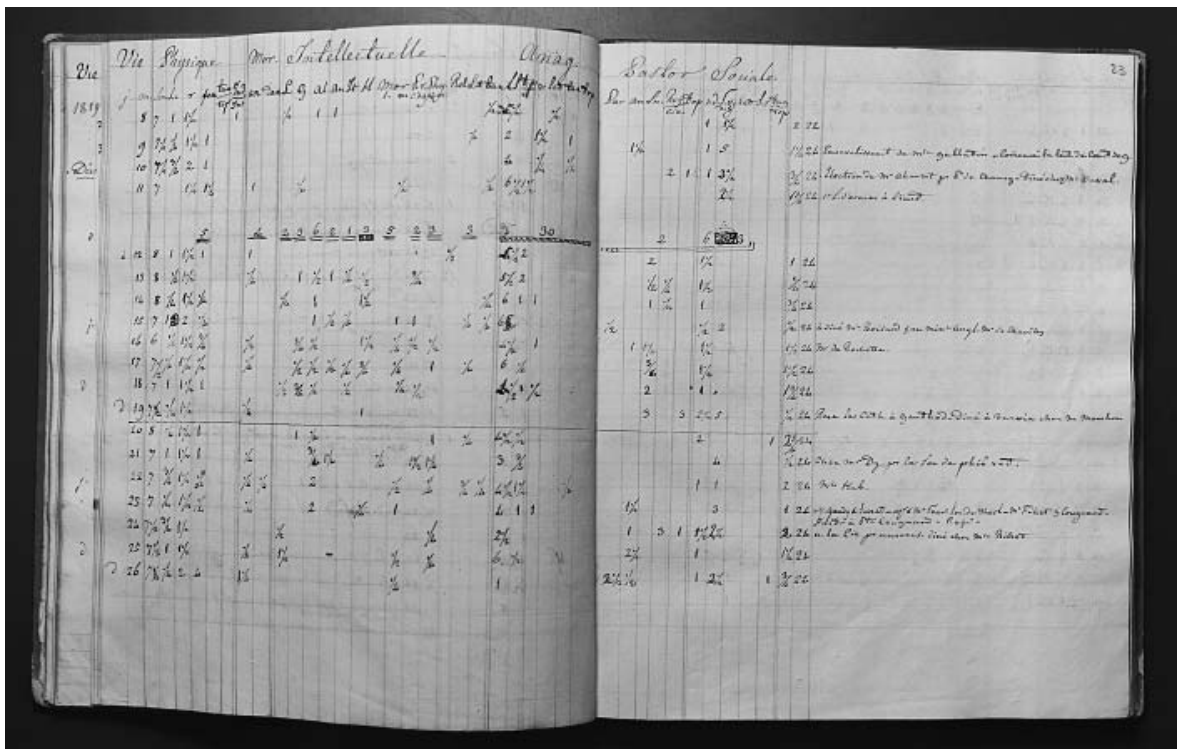

Figure 7 Sample of François-Marc-Louis Naville's adaptation of Marc-Antoine Jullien's moral thermometer or biometer (underlined figures are targets for activities per week). This sample shows the substantial time Naville devoted to his anagogical activities. Source: State Archives of Geneva, archives of the Naville family (Naville XIII B-1.2/10: 22-23). Photograph Marius Kuster.

control. Jullien referred to these hours as the residu de la vie, the life residual. Column $\mathrm{Q}$ contained the numbers of hours in the day. A comparison between $\mathrm{P}$ and $\mathrm{Q}$ would give a measure of time lost, of waste, or conversely of the efficiency with which total time was spent. Jullien made two provisos. First, it could be that time spent in one category would also contribute to another. Having a meal made part of physical care, but having a meal with friends could also be registered as social life. The total number of hours usefully spent could therefore surpass 24 hours and would effectively mean an expansion of the day. Second, Jullien warned that one should not strenuously try to bring down the life residual to zero, because some waste was "inevitable."

Jullien's original table (Fig. 6) contained a second measure of moral worth, however. The last two columns, R and S, were included to make an overall assessment of the value of a day, not in terms of time, but in terms of a person's sentiment about how well the day was spent. In column $\mathrm{R}$ a person could write specific comments, and $\mathrm{S}$ provided a general evaluation in terms of plus or minus, or any other symbol a person saw fit. In a later edition of his essay, Jullien reported how pleased he had been with the "perfection" given to his table by Marc-Auguste Pictet, successor of Horace-Bénédict de Saussure in the chair of physics at the Academy of Geneva. ${ }^{12}$ Pictet designed a diagram that summarized the sentiment of the day in a graph running between +10 degrees of happiness and -10 degrees of pain (Fig. 8). Reading from bottom to top, the diagram visualized this personal judgment as a continuous graph connecting the

\footnotetext{
12 Marc-Auguste Pictet was a member of the famous Pictet banquers family, which still belongs to the Swiss patriciate. Horace-Bénédicte de Saussure is known for his Mont Blanc expedition and is considered the Swiss Alexander von Humboldt.
} 


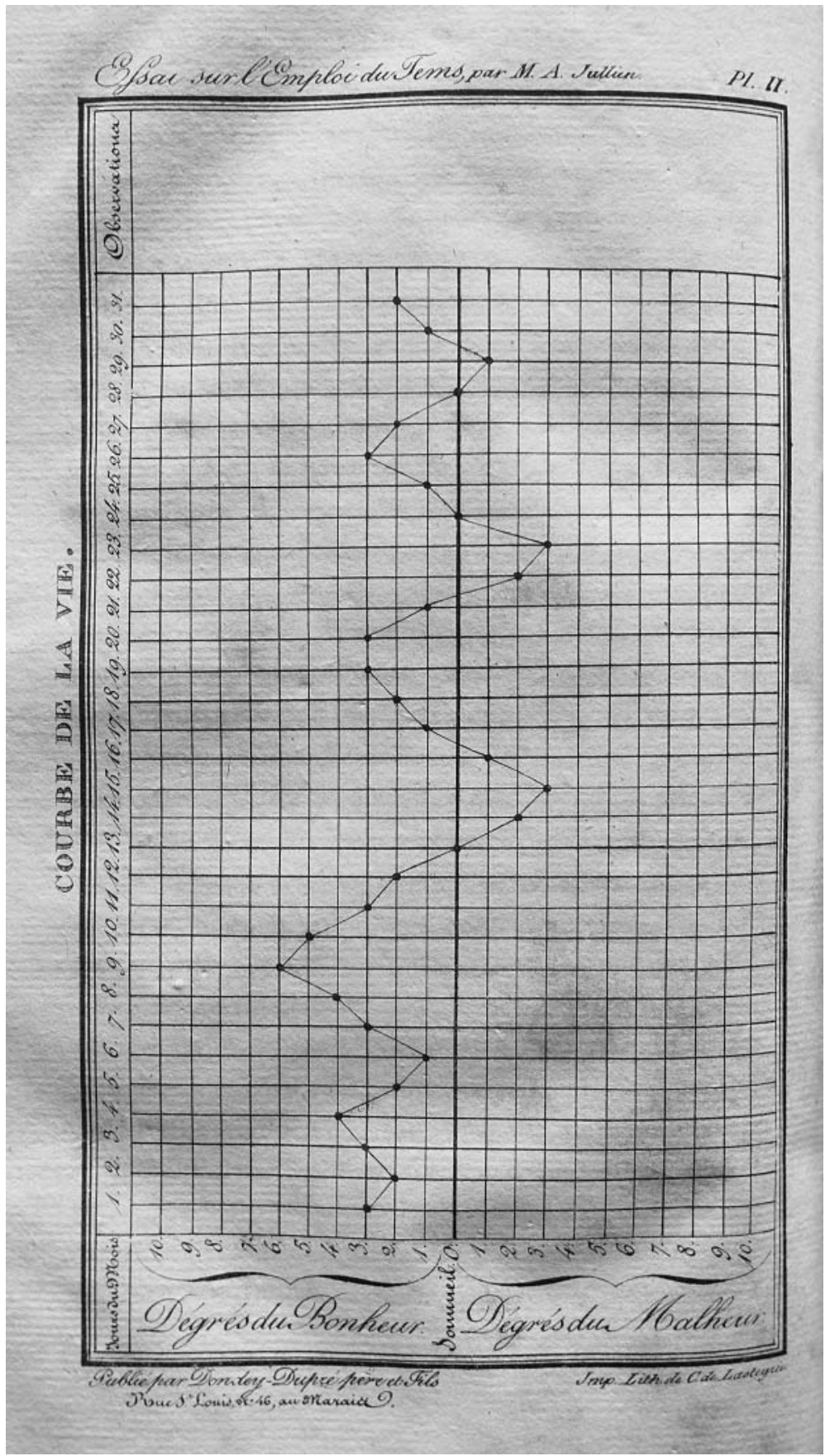

Figure 8 "Curve of life." This instrument was presented to Marc-Antoine Jullien by Marc-Auguste Pictet, successor of Horace-Bénédict de Saussure as chair of physics at the Academy of Geneva, who suggested its use in combination with, and not as a replacement for, Jullien's moral thermometer (Jullien 1810). Photograph Marius Kuster. 
individual dots, adding movement and the suggestion of precision to Jullien's evaluative last column. In Pictet's diagram, the yardstick of moral conduct was not the efficient use of time, but the utilitarian criterion of maximizing pleasure and minimizing pain.

Jullien's table thus takes us to measures of worth that became centered around notions of efficiency, pleasure, and pain, and a work schedule for the day. It thus should come as no surprise that Jullien, writing at the dawn of the Industrial Revolution, showed great interest in Robert Owen's social experiment in New Lanark that introduced monitoring methods of his workmen and their families, just as it may explain the interest of the Genevese community of which Pictet and Naville were a part in Jeremy Bentham's utilitarianism (Bartle 1991; Barthes 1971; Blamires 2009; Roth 1977; Trincado and Santos-Redondo 2017; Eyguesier n.d.). Mercantile Geneva, in France suspiciously referred to as "la banque protestante" because of its alleged financial influence on French political affairs (Lüthy 1964, 1998), provided a fruitful environment for monitoring methods that connected moral improvement to ideas about work, waste, and utility.

\section{True Grit}

In this paper I reviewed three methods of moral accounting. The Chinese ledger system, propagated by Yuan Huang in the late Ming period, provided an intricate system of calculating someone's moral worth that was embedded in a system of rules and practices that combined Buddhist, Daoist, and neo-Confucian strands of thought. Benjamin Franklin's Art of Virtue used tables to train someone in a variant of the canonical virtues. Marc-Antoine Jullien developed a registering device that enabled an individual to keep detailed track of his time expenditures in different domains of life.

All three methods used gridded tables to perform their accounting procedures. I examined in some detail the scripts of these tables. Working through the grids of the tables, its users gradually built an image of their moral selves, of their characters. But the scripts of these tables functioned differently. In Yuan Huang's ledgers the grids were filled with numbers that referred to the moral and celestial value of the deeds of a person. Depending on the shape of the tables, the numbers in the grids showed higher or lower levels of aggregation, from which it was more or less easy to read the social categories that were affected by a person's deeds. The character that emerged from the grid was at once personal and social.

The grids of Benjamin Franklin's tables did not ask to be filled, but to remain empty. Franklin's Art of Virtue was a method of suppression, of moral restraint, that valued personal control over social ties. This did not mean that social ties were absent from Franklin's thirteen virtues. But the empty spaces showed that Franklin was in control of the virtue under review. Empty spaces became valued as an index of his moral standing.

Jullien's biometer scripted moral character in terms of time spent on the different categories of life. By filling in the grid, a person acquired insight into his moral character and discovered points for improvement. In contrast with the Chinese ledgers, Jullien's tables were not intended to circulate socially. Moral improvement was a personal goal that was measured along two different axes: time and personal 
satisfaction. Jullien's tables moved in the direction of work schedules and the optimization of the use of time, either to increase personal happiness, or to increase one's moral worth in the face of God's grace.

All three grids objectified what it meant to be and to do good. We have seen that the spatial layout and the categories and rules of use that accompanied these grids enabled and constrained the kind of moral calculations that could be made with their help. With these, as Jullien wrote, "moral mirror," "moral thermometer," "moral panorama," its users acquired knowledge about their conduct that helped them to improve, to build character. But we have also seen that character meant different things in different social contexts. These wider institutional contexts secured their meaning: the religious cloisters and Imperial bureaucracy in the case of Yuan Huang's ledgers, an increasingly commercial and industrial society in the case of Franklin's and Jullien's respective systems. Thus, the grids of our three case studies not only mirrored the character of their users but also the societies in which they were produced. Relative to these social contexts these instruments of moral improvement helped their users to acquire, as in the classic American western, True Grit. ${ }^{13}$

\section{References}

Aho, James A. 2005. Confession and Bookkeeping: The Religious, Moral, and Rhetorical Roots of Modern Accounting. Albany: State University of New York Press.

Akrich, Madeleine. 1987. "Comment décrire les objets techniques?" Technique et culture 9: 49-64.

Akrich, Madeleine. 1992. "The De-Scription of Technical Objects.” In Shaping Technology/Building Society: Studies in Sociotechnical Change, edited by Wiebe E. Bijker and John Law, 205-24. Cambridge, MA: MIT Press.

Barthes, Roland. 1971. Sade, Fourier, Loyola. Paris: Seuil.

Bartle, George F. 1991. "Benthamites and Lancasterians: The Relationship between the Followers of Bentham and the British and Foreign School Society during the Early Years of Popular Education." Utilitas 3, no. 2: 275-88.

Blamires, Cyprian. 2009. "Bentham, Dumont, et le panoptique." In Bentham et la France: Fortune et infortunes de l'utilitarisme, edited by Emmanuelle de Champs and Jean-Pierre Cléro, 97-110. Oxford: Voltaire Foundation.

Brokaw, Cynthia. 1987. "Yüan Huang (1533-1606) and the Ledgers of Merit and Demerit." Harvard Journal of Asiatic Studies 47, no. 1: 137-95.

Brokaw, Cynthia Joanne. 1991. The Ledgers of Merit and Demerit: Social Change and Moral Order in Late Imperial China. Princeton, NJ: Princeton University Press.

Castelvetro, Lodovico. (1653) 1983. Esaminatione sopra la ritorica a Caio Herennio. Modena, Italy: Andrea e Girolamo Eredi del Cassiani.

Chakhovich, Terhi, and Elton G. McGoun. 2016. "Why Grids in Accounting?" Critical Perspectives on Accounting 34: 36-59.

Chiffoleau, Jacques. 2011. La comptabilité de l'au-delà: Les hommes, la mort et la religion dans la région d'Avignon à la fin du moyen âge (vers 1320-vers 1480). Bibliothèque de l'évolution de l'humanité, vol. 59. Paris: Albin Michel.

Coen, Ethan, and Joel Cohen, dirs. 2010. True Grit. Los Angeles: Paramount Home Entertainment. Blu-ray/ DVD combo pack, 1080p high definition.

\footnotetext{
13 True Grit is an American Western story of a teenage girl who enlists the help of a tough Marshal (and a hit man) to track down the murderer of her father. In their search, in which the girl loses an arm, the girl showsto the amazement of the Sheriff and hit man-exceptional courage and character. The original film of 1969 and its remake by the Coen brothers of 2010 were both based on a book by Charles Portis with the same title.
} 
Coquery, Natacha, François Menant, and Florence Weber, eds. 2006. Écrire, compter, mesurer: Vers une histoire des rationalités pratiques. Paris: Rue d'Ulm.

Di Rienzo, Eugenio. 1999. Marc-Antoine Jullien de Paris (1789-1848): Una biografia politica, vol. 3. Naples, Italy: Guida Editori.

Engammare, Max. 2010. On Time, Punctuality, and Discipline in Early Modern Calvinism. Cambridge: Cambridge University Press.

Eyguesier, Nicolas. n.d. "Owen as Read by Marc-Auguste Pictet (1752-1825) and Sismondi (1773-1842)." Unpublished manuscript.

Fallan, Kjetil. 2008. "De-Scribing Design: Appropriating Script Analysis to Design History.” Design Issues 24, no. 4: 61-75.

Gibson, James J. 1979. The Ecological Approach to Visual Perception. Boston: Houghton, Mifflin, and Company.

Guo, Daoyang, Yialin Xu, Lan Peng, and Jinxiu Zhang. 2011. "China.” In A Global History of Accounting, Financial Reporting, and Public Policy: Asia and Oceania, edited by Gary J. Previts and Peter Walton, 35-105. Bingley, UK: Emerald.

Hess, Volker, and J. Andrew Mendelsohn. 2010. "Case and Series: Medical Knowledge and Paper Technology, 1600-1900." History of Science 48, no. 3-4: 287-314.

Hopwood, Anthony G. 1994. "Accounting and Everyday Life: An Introduction.” Accounting, Organizations, and Society 19, no. 3: 299-301.

Hoskin, Keith, Debin Ma, and Richard H. Macve. 2013. "A Genealogy of Myths about the Rationality of Accounting in the West and in the East." November 27. dx.doi.org/10.2139/ssrn.2389309.

Houston, Alan, ed. 2008. Franklin The Autobiography and Other Writings on Politics, Economics, and Virtue. Cambridge: Cambridge University Press.

Huang, Yuan. 1988. “Gongguoge Fenlei Huibian.” In Congshu Jicheng Xubian, 239-57. Taipei, Taiwan: Xin Wenfeng Press.

Jullien, Marc-Antoine. 1810. Essai sur l'emploi du tems; ou, méthode qui a pour objet de bien régler sa vie, premier moyen d'être heureux; destinée spécialement à l'usage des jeunes gens de 15 à 25 ans. Paris.

Jullien, Marc-Antoine. 1813. Mémorial horaire, ou thermomètre d'emploi du tems . . . pour l'année 18. Paris.

Jullien, Marc-Antoine. 1835. Essai général d'éducation physique, morale et intellectuelle, suivi d'un plan d'éducation-pratique pour l'enfance, l'adolescence et la jeunesse, ou recherches sur les principes et les bases de l'éducation. 2nd ed. Paris.

Kohn, Livia. 1998. "Counting Good Deeds and Days of Life: The Quantification of Fate in Medieval China." Asiatische Studien 52, no. 3: 833-70.

Lehnert, Martin. 2004. Partitur des lebens: Die Liaofan Si Xun von Yuan Huang (1533-1606). Bern: Peter Lang.

Lejeune, Philippe. 2011. "Marc-Antoine Jullien: Controlling Time.” In Controlling Time and Shaping the Self, edited by Arianne Baggerman, Rudolf M. Dekker, and Michael James Mascuch, 95-120. Leiden, the Netherlands: Brill.

Lejeune, Philippe, and Catherine Bogaert. 2003. Un journal à soi: histoire d'une pratique. Paris: Textuel.

Lüthy, Herbert. 1964. "Calvinisme et capitalisme: Les thèses de Max Weber devant 1'histoire." Preuves 161: 3-22.

Lüthy, Herbert. 1998. La banque protestante en France: de la révocation de l'Édit de Nantes à la révolution, vol. 2. Paris: Éditions de l'école des hautes études en sciences sociales.

Maas, Harro. 2019. "Monitoring the Self: François-Marc-Louis Naville and His Moral Tables." History of Science, October 16. doi.org/10.1177/0073275319876851.

Mendelsohn, J. Andrew. 2011. "The World on a Page: Making a General Observation in the Eighteenth Century." In Histories of Scientific Observation, edited by Lorraine Daston and Elizabeth Lunbeck, 396420. Chicago: University of Chicago Press.

Miller, Peter, and Ted O'Leary. 1987. "Accounting and the Construction of the Governable Person." Accounting, Organizations, and Society 12, no. 3: 235-65.

Palmer, R. R., trans1. 1993. From Jacobin to Liberal: Marc-Antoine Jullien, 1775-1848. Princeton, NJ: Princeton University Press.

Portis, Charles. 1968. True Grit. New York: Simon and Schuster.

Puyou, François-Régis, and Paolo Quattrone. 2018. "The Visual and Material Dimensions of Legitimacy: Accounting and the Search for Socie-Ties.” Organization Studies 39, nos. 5-6: 721-46.

Quattrone, Paolo. 2004. "Accounting for God: Accounting and Accountability Practices in the Society of Jesus (Italy, XVI-XVII Centuries).” Accounting, Organizations, and Society 29, no. 7: 647-83. 
Quattrone, Paolo. 2009. "Books to Be Practiced: Memory, the Power of the Visual, and the Success of Accounting." Accounting, Organizations, and Society 34, no. 1: 85-118. doi.org/10.1016/j.aos.2008 03.001 .

Roth, Robert. 1977. "Prison-modèle et prison symbole: L'exemple de Genève au XIXème siècle." Déviance et Société 1, no. 4: 389-410.

Trincado, Estrella, and Manuel Santos-Redondo. 2017. Economics, Entrepreneurship, and Utopia: The Economics of Jeremy Bentham and Robert Owen. New York: Routledge.

Walker, Stephen P. 1998. "How to Secure Your Husband's Esteem: Accounting and Private Patriarchy in the British Middle Class Household during the Nineteenth Century." Accounting, Organizations, and Society 23, nos. 5-6: 485-514. doi.org/10.1016/S0361-3682(97)00025-1.

Yamey, Basil S. 2005. "The Historical Significance of Double-Entry Bookkeeping: Some Non-Sombartian Claims." Accounting, Business, and Financial History 15, no. 1: 77-88. doi.org/10.1080/095852005000 33089.

Yuan, Weipeng, Richard H. Macve, and Debin Ma. 2017. "The Development of Chinese Accounting and Bookkeeping before 1850: Insights from the Tŏng Tài Shēng Business Account Books (1798-1850)." Accounting and Business Research 4, no. 4: 401-30.

Harro Maas is a professor of history and methodology of economics at the Centre Walras-Pareto for the History of Economic and Political Thought of the Faculty of Social and Political Sciences at the University of Lausanne. He has written about changing methods of observing, modeling, and visualizing the economy in the nineteenth and twentieth centuries. He is currently working on a history of moral accounting and consumer governance, which is funded by the Swiss National Science Foundation. He is the author of William Stanley Jevons and the Making of Modern Economics (2005) and Economic Methodology, A Historical Introduction (2014), and he is the coeditor of Histories of Observation in Economics (2012) and The History of Experimental Economics: A Witness Seminar on the Emergence of a Field (2016). 